\title{
Relative efficacy of newer insecticides against Helicoverpa armigera (Hubner) in tomato under South Gujarat condition
}

ARCHANA T. AMBULE *, G.G. RADADIA, C.U. SHINDE AND DINESH L. PATIL

Department of Entomology, N.M. College of Agriculture, Navsari Agricultural University, NAVSARI (GUJARAT) INDIA

\section{ARITCLE INFO}

Received : 08.04 .2015

Revised : 28.07 .2015

Accepted : 12.08 .2015

\section{KEY WORDS :}

Relative efficacy, Helicoverpa armigera (Hubner), Tomato

*Corresponding author:

Email: lakshminem@gmail.com

\begin{abstract}
Field experiment conducted on relative efficacy of nine different insecticides against H. armigera (Hubner) in tomato during year 2012-13 revealed that all the nine insecticides were significantly superior to untreated control in reducing $H$. armigera infestation. However, flubendiamide 0.004 per cent recorded minimum larval population ( 0.43 larva/ plant) and 10.09 per cent fruit damage on weight basis than the remaining treatments which was identical with chlorantraniliprole 0.0055 per cent $(0.58$ larva/plant and 10.62 $\%$ fruit damage) and spinosad 0.0068 per cent ( 0.68 larva/plant and $11.34 \%$ fruit damage). Higher marketable yield recorded from treatments of flubendiamide 0.004 per cent chlorantraniliprole 0.0055 per cent and spinosad 0.0068 per cent with $25.21,24.84$ and 22.20 tonnes/ha, respectively.
\end{abstract}

How to view point the article : Ambule, Archana T., Radadia, G.G., Shinde, C.U. and Patil, Dinesh L. (2015). Relative efficacy of newer insecticides against Helicoverpa armigera (Hubner) in tomato under South Gujarat condition. Internat. J. Plant Protec., 8(2) : 250-255. 